\title{
Innovativeness as part of quality and excellence development in the Slovenian public administration (survey results 2007-2008)
}

UDK: 005.336:35(045)

\section{Polonca Kovač}

University of Ljubljana, Faculty of Administration polona.kovac@fu.uni-lj.si

\author{
Barbara Leskovšek \\ University of Ljubljana, Faculty of Administration \\ barbara.leskovsek@fu.uni-lj.si
}

\begin{abstract}
The purpose of the study was (1) to investigate the trends in the development of excellence and innovativeness, or the use of the relevant tools, by comparing the situations of 2003, 2006 and (as projected) 2009 to one another, and against the approaches used in companies, and (2) to encourage the spread of awareness within the public administration of the importance of identifying and spreading good practices. We found that trends are taking the same direction, with the number of different tools and the frequency of their use - especially of the CAF (Common Assessment Framework) and EFOM (European Foundation for Quality Management) models, partly also the BSC (Balanced Scorecards), and of ISO standards - being on a continual rise, while the main systemic deficiencies are the inconsistent top-down policy of quality and excellence development, and the non-existent methodology for empirical evaluation of the effects produced by the use of those tools. The organisations are left to their own initiative, and support of the Government and the Ministries is only declarative. Innovativeness, unlike this, primarily entails gradual improvements in the ways in which work is done - in the first place from the client perspective -, which is mainly reflected by the estimated financial savings.
\end{abstract}

Key words: public administration, quality and excellence, innovativeness, organisation

JEL: H 83, L15, O31, D73 
Polonca Kovač, Barbara Leskovšek

Innovativeness as part of quality and excellence

development in the Slovenian public administration

\section{Introduction}

This paper entitled »Innovativeness as part of quality and excellence development in the Slovenian public administration « presents the results of the "Study on business excellence in relation to the use of tools for continuous improvement and innovativeness and for higher quality and excellence in the organisations in the Republic of Slovenia " conducted, mostly in 2007, by the Faculty of Administration in cooperation with the Metrology Institute of the Republic of Slovenia and the Faculty of Organisational Sciences of the University of Maribor. The study on business ${ }^{1}$ excellence in Slovenia, more specifically on the use of tools for quality and excellence development and continuous improvement with special emphasis on establishing the significance of innovativeness in the organisations covered by the study, examined the correlations between innovativeness and business excellence of organisations on one hand and the comparison between large, small and medium-sized enterprises and the organisations of public administration on the other. The purpose of the research was mainly applicative considering that the common aim of both the requesting and the implementing institutions was to obtain empirical analyses of the actual and planned use of quality development tools in time and by type of organisation, to be used as basis for the strategy of further quality development in public administration. Moreover, by means of data gathering the organisations would perceive the strategic interest in the development of the matter, whereby the study would have achieved its objective of raising the awareness of the competent authorities about the significance of business quality development (also) in public administration. In the latter part, the study focused on demonstrating the assumed correlation between wide-spread and increasingly used quality tools and greater innovativeness of work. In order to better understand the applicative part of the study, a presentation of some basic notions already anticipated by the title of this paper are presented below. The theoretical part will be followed by an empirical demonstration of the main outcomes of the study.

In the theory of economics, innovativeness is one of the factors of economic growth and a driving force of development. Innovation and innovativeness both have a positive connotation, meaning something which is useful and

1 The EFOM model from which the above definitions are taken initially referred to "business excellence" and began to use the term "excellence" only after its renewal in 2003 (and in Slovenian documents even later). For the purposes of this paper, the two terms are regarded as synonyms. 
brings progress and greater satisfaction. Innovativeness is closely related to creativity: in fact, an idea would first come up and would (can) be transposed into reality only by means of innovativeness. An organisation is deemed innovative when it carries out a certain task in a manner different than usual for a specific work post, or when it offers its clients a new service in a different and better manner (e.g. online services). In public administration, innovations are defined as introduction of new services, organisational forms, processes and management methods not hitherto applied ${ }^{2}$. Nemec ${ }^{\mathbf{3}}$ points out that public administration is more familiar with the notion of change, possibly for the better, or kaizena i.e. gradual and non-revolutionary or non-radical improvement.

The next notion anticipated by the title of this paper and calling for an explanation is quality. The higher the quality, the greater the value of products and services for all the parties in terms of policy and finance. Total quality management (TOM) focuses on procedures and processes that are considered as quality assurance tools. A higher degree of quality is excellence, i.e. the exceedance of the needs, requirements and expectations of the clients and all the parties involved in the work of the organisation. According to CAF 2006 (Common Assessment Framework for organisations in the public sector/model CAF, 2007), excellence means best practice in the management of the organisation and the achievement of results based on a series of basic principles of total quality management as provided by the EFOM (European Foundation for Quality Management) model (Savič et al., 2007).

Public administration is a notion that lacks a uniform definition and includes state administration bodies and part of the public services; in addition, it may include local self-government bodies with local public services, i.e. all organisations of the territorial as well as functional type performing duties of public importance or the public duty of providing public amenities ${ }^{4}$. Public administration operates with written documents and performs time-defined and continued tasks based on legal or technical rules; its functional and hierarchical organisation is focused on centralisation. Public administration is defined not only in terms of function (definition of functions and duties in public interest) or organisation (permanent structures with defined human, financial and other resources), but also in terms of procedure - given the definition of procedures as guarantees of (formal) legality (Kovač, 2006). Public administration

2 Loeffler, 2006, p. 23, comp. Virant, 2007.

3 In Žargi et al., 2007, p. 203.

4 Šmidovnik, 1985, p. 129-130. 
Polonca Kovač, Barbara Leskovšek

Innovativeness as part of quality and excellence

development in the Slovenian public administration

is characterised by superior-subordinate relationships whereby superior is the body holding the power, while under private law the prerequisite is the equality of the parties ${ }^{\mathbf{5}}$. According to Pirnat ${ }^{\mathbf{6}}$, the main problem in the legal definition of administration-related notions is that one tries to impose legal norms on empirical notions, analysing them with strict formal rules of logic and legal science; the consequence of generality and abstractness is inconsistence between the actual and the normative.

The previously mentioned study of the use of quality and excellence tools and thus of promoting continuous improvement and organisational innovativeness development was based on the assumption that regardless of the area of operation of individual organisations, there is a correlation between business quality development and innovativeness. The organisations fostering quality and excellence development (Marolt and Gomišček, 2005), mainly by investing into the relevant resources and the use of TQM tools with emphasis on internal and external evaluation procedures, create a stimulating environment for innovations at the level of individual employees and the organisation as a whole. Consequently, the systemic development of innovativeness leads to higher business quality (Nemec, 2003). In such context, two basic research questions were developed and studied with the following hypotheses: (1) the public administration does not (yet) systematically use the tools for the development of excellence and innovativeness, and (2) as regards the extent and the results of the use of different excellence tools, a higher degree of innovativeness and better business results are achieved by the organisations that invest more in their employees and organisational development. The purpose of the study was therefore to prove the hypothesis that in public administration quality development tools are still used in a non-systematic manner although the organisations using them achieve better results in employee innovativeness and overall satisfaction with the organisation's work.

\section{Methodology}

The selection of the organisations covered by the study was made in accordance with the definition of public administration. The study was conducted by means of a survey questionnaire involving a highly representative sample composed of ministries, bodies affiliated to ministries, administrative units and

5 Pavčnik, 1997, p. 437.

6 1988, p. 9, in Kovač, 2006. 
government services - i.e. the state administration bodies. The largest share of addressees belonged to municipal administrations, and the study also included social work centres and public institutes. In total, the sample comprised over 400 organisations of public administration. The level of response exceeded the expectations as 140 questionnaires were returned (Figure 1), meaning that over $33 \%$ of all addressees participated in the study. This confirmed the authenticity of data gathered and analysed for the purpose of the study.

\section{Figure 1: Share of addressees per type of body (out of 140)}

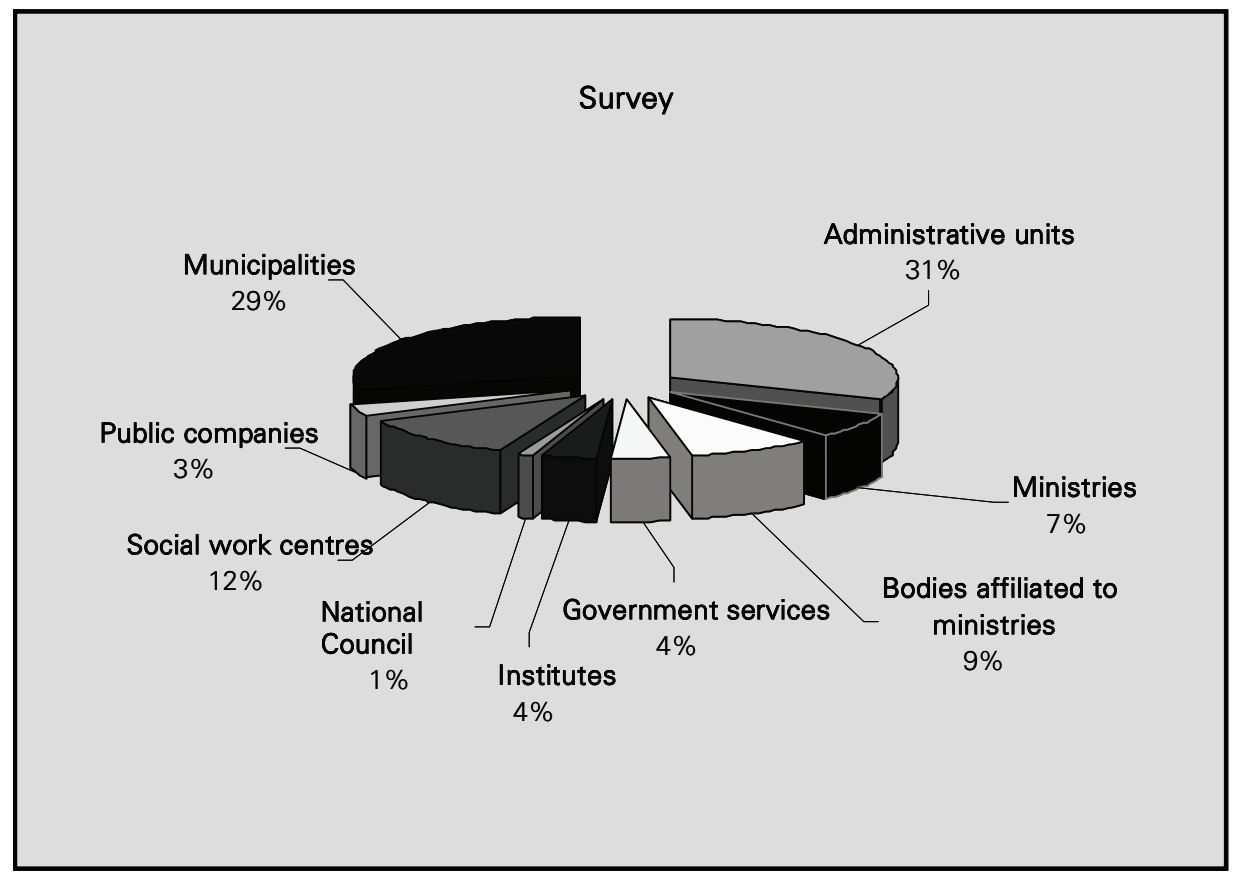

A systematic approach was chosen to carry out the research (Toš and Fink, 1998), from the definition of the problem and development of research questions (based on the prevailing expert opinion) to the application of the method of research with preliminary data gathering and substantiated confirmation/rejection of the research questions. Methods of research in the field of social sciences were applied.

The study covers both the theoretical-dogmatic and the empirical aspects of the use of tools to increase quality and excellence in the public administration or in the private sector in Slovenia. The first aspect is reflected in the definition of the basic notions determining the scope of the study. Dogmatism is 
Polonca Kovač, Barbara Leskovšek

Innovativeness as part of quality and excellence

development in the Slovenian public administration

expressed also in the definition of the frameworks of empirical research (definition of public administration and, thus, the respondents' organisations, etc.), and even more in the interpretation of statistical results. The entire research is however dominated by the second aspect since the main objective of the project is to gather and process data on the use of tools and on investments into innovativeness and development of business excellence in practice. Empirical methods are in fact indispensable for dealing with a world of facts where practical experience is taken into consideration. Moreover, in order to study the world of theoretical definitions a descriptive method needs to be applied, i.e. an analysis of the content of individual notions, the definition thereof in legislation and within the context of individual approaches and textbooks, their interpretation and comparison. The described duality of notions is thus essential also for the duality of the applied methods and findings of this study.

In most cases also the sociological method was used, mainly considered as the basic method when it integrates certain elements of public administration into real social life, taking into account the formulation of legal norms in the light of prevailing social values. However, the sociological method can not be the only one as it is based on the respect of existing legislation only. Nevertheless, it brings to interesting conclusions concerning the relationship between law and society and vice versa. The project activities were divided into three stages: (1) formulation of theoretical basis, (2) data gathering, and (3) their statistical and content-related analysis.

The empirical part of the research was based on the case study method.

The surveys and additional talks with respondents' representatives and other participants in the study brought to light mostly practical issues. The survey research method enables to gather quantitative data and is considered a quantitative method. In fact, a survey is any collection of data obtained by asking questions, which may be carried out in various ways. Surveys may be either individual or relate to a group, they can be made by mail, e-mail, website, telephone, etc. There are many types of questions to be asked, depending on a number of criteria (content, manner of responding, significance in the questionnaire, indirect/direct questions, special purpose, etc.) (from http://www.znanstveniki.si/; Ambrožic, 2005).

For the purposes of this study, all possible forms of questions by manner of responding were used. Open questions allowed the respondents to give a free answer expressed with their own words; closed questions offered alternative answers; and semi-open questions enabled them to provide either a 
free answer to the posed question or an answer corresponding to the suggested answer categories. The survey questionnaires sent by regular or electronic mail provided data from certain organisations covered by the study; the obtained results were then generalised by survey group or sample and compared. To increase the survey sample, organisations were called to cooperate a few times by mail, telephone, and the Internet. The persons failing to respond after two additional letters were sent a reminder with a copy of the questionnaire?.

The study collected data relating to 2003, 2006 and 2009. The year 2006 was set as the reference year considering that the organisations responded to the survey mainly between June and August 2007, thus providing available secondary statistical data for the latest entire calendar period i.e. the year 2006. The periods of three years before and after the reference year (data for 2009 is based on projections) were defined in line with the experience and practice of the European Foundation for Quality Management (EFOM) in Brussels. In all questionnaires, data was first statistically analysed by calculation in Excel, after which it was processed and analysed in SPSS (Statistical Package for Social Sciences).

\section{Presentation of excellence assessment tools}

With the aim of achieving the better (best), various tools and approaches were developed (more in Dolinšek et al., 2006, Kovač, 2007). First, there were individual (mainly economic) indicators, followed by quality assurance standards defining minimum criteria, the most widely known being the ISO 9000 quality management system. In a few decades following the 2nd World War, a radical upgrading took place and various quality models were developed which, contrary to the standards, aimed at promoting continuous improvement and known as quality management. Prior to proceeding to the empirical part of the study, it is necessary - in order to allow greater uniformity of terms, better understand the applied results and obtain the relevant data considering the identification of basic notions (and the interpretation thereof) - to present the excellence tools developed by national and foreign scientists which served as basis for the questions used in the survey.

7 Kalton and Vehovar, 2001, p. 83 
Polonca Kovač, Barbara Leskovšek

Innovativeness as part of quality and excellence

development in the Slovenian public administration

One of the most widely used standards is indeed the EFOM European Excellence Model, known also in Slovenia in relation to the Slovenian Business Excellence Award (PRSPO). In addition, the Slovenian public administration uses standards and approaches such as the Quality Barometer, customer and staff satisfaction surveys, SiOK - Slovenian Organisational Climate, Investors in People, the system of financial indicators of performance and efficiency, Balanced Scorecards, etc. Nevertheless, the most important is the CAF model for the public sector.

The EFQM Excellence Model was designed in the 1980s and in 1992 served as basis for the European (business) excellence award, initially awarded for the private sector but today including categories of large, small and medium-sized enterprises and the public sector. Its partner organisation in Slovenia is the Metrology Institute in the context of the Slovenian Business Excellence Award (PRSPO). The PRSPO award was developed in the first years of Slovenia's independence under the national quality programme - following the example of the EFOM Excellence Award EEA and national awards in other Member States - to support competitiveness enhancement policies in all areas of work of the State. The basis for any activity in such field is provided by the European criteria of excellence and assessment thereof, developed by the EFQM. The purpose of the award is to encourage Slovenian companies, institutes and other legal entities as well as state bodies to introduce the systems for modern, efficient and full achievement of quality and business excellence.

As regards quality, Slovenia was among the first countries in Europe to use the Common Assessment Framework (CAF) for organisations in the public sector. This model, designed in 1998 as a pilot project under the auspices of the European Commission and the European Institute of Public Administration and in regular use since 2000, may be used for self-assessment or for external assessment and competition. A distinctive feature of the CAF model is that it takes into account the specifics of public administration, e.g. the importance of the attitude toward customers, non-financial performance indicators, etc.

ISO (International Organisation for Standardisation) is a global network determining which international standards need to be applied on work, within the Government and within the society, developing them in partnership with the sectors where they are to be used, summarising them by means of transparent procedures based on national inputs, and making them available on a global scale. ISO standards determine the requirements for state-of-the-art products, services, procedures, materials and systems, and for adequate assessment of compliance, 
management and organisational practice (Common Assessment Framework for organisations in the public sector/model CAF, 2007).

The Balanced Scorecards (BSC) system is a tool used to transfer strategy into the operation of an organisation, originated in the late 1980s by Harvard professors Robert S. Kaplan and David P. Norton. Measuring the results by BSC allows the companies' managements to define the objectives that exceed the mere financial performance and include investments in people and in the improvement of processes by which long-term performance may be guaranteed. The BSC system is a managerial tool for managing the organisation's strategy and measuring performance, not for designing the strategy ${ }^{\boldsymbol{8}}$.

The Quality Barometer is a tool or method to assess customer satisfaction with the work of the administration. Thus, it supplements similar approaches that have been in force for some years now, particularly the customer satisfaction surveys in administrative units (since 2001) and other bodies. The Quality Barometer assesses customer satisfaction on a monthly basis. The respective questionnaire relates to four parameters of operation of an organisation: quality of staff work, staff attitude, velocity of the work done, and arrangement and accessibility of the organisation.

The Excellence Measurement System in Slovenian Public Administration (SOOJU) is a system developed in 2007 by the Faculty of Administration under the project commissioned by the Ministry of Public Administration and the Metrology Institute, using the CAF 2006 model and the Decree on Administrative Operations. The aim of the project was to develop and set up an external excellence assessment system in the organisations of the Slovenian public administration based on the European model (framework) for the public sector CAF and the Decree on Administrative Operations in the part relating to standards of public administration operations with the users of public services (22 standards were defined in the project).

8 Kaplan and Norton, 2000, p. 19-20 
Polonca Kovač, Barbara Leskovšek

Innovativeness as part of quality and excellence

development in the Slovenian public administration

\section{4. (Non) use of excellence/innovativeness development tools}

The research questions gave the following results:

1. The organisations of public administration do not (yet) use the excellence and innovativeness development tools in a systematic manner. This question was further examined through 9 sub-questions.

The analysis revealed that on the average the majority of organisations (from 62 to $67 \%$ of all returned questionnaires) kept systematic records of the number of employees on several issues. As regards monitoring and assessing the number of training days per employee, organisations kept record in 50$60 \%$ of the cases. Financial resources are monitored and assessed mainly in relation to training (57-67\%) and less in relation to improvements and innovativeness (44-47\%) or research and development (39-42\%). The above partly confirms the finding of the second part of the question (see below), namely that organisations do not monitor their employees with systematic and structured data relating to improvement/quality and innovativeness - in fact, the results showed that on the average organisations monitored and kept record of the proposals for improvement and innovation to a lesser extent (34-37\%) or not at all (49-52\%); likewise, also who and how many employees had presented proposals was monitored less (34-38\%) or not at all (49-52\%). Organisations do not keep systematic and structured records of the implementation of the received proposals (30-36\%) or do not examine such fact at all (50$57 \%)$. The estimated net savings as a result of the implemented proposals for continuous improvement and innovation were monitored in a limited number of cases (17-22\%) or not at all (65-69\%). Quite similarly, data regarding the amount of the reward given to employees for their proposals and improvements was kept in a small number of cases $(23-29 \%)$, or the organisation did not keep track thereof at all (57-63\%). In such context, many respondents stressed that data thereon was not kept as there was no particular interest in such monitoring.

In the period 2003-2006, the average number of days of employee training in quality management and business excellence was 144.95, in raising innovativeness 41 , in human resources development 86.5 , and in managerial skills improvement 79. In all areas of training, the same trend was recorded 
also in the period until 2009. The linear trend calculated independently from the data received in the survey questionnaires provided a picture very similar to other statistical calculations, namely that the number of days devoted to employee training was steadily increasing between 2003 and 2006, which would certainly continue also in the period until 2009. Among the four areas under consideration, the highest figures were recorded in days of training in quality improvement and innovativeness, which points to a high degree of management and staff awareness that the quality of work and innovative solutions by employees are an important aspect of performance also in the public administration.

The analysis also showed that in 2006 organisations with 26 to $50 \mathrm{em}$ ployees considered the certified system of business quality management ISO 9001:2000 to be most important procedure. 2009 is expected to see a further increase in the share of organisations with similar staff numbers that find such procedure most important. The majority of organisations which in 2009 find it most important to be evaluated by external evaluators based on the CAF model or to participate in the pilot project of external evaluation according to the same model (public sector) are those with 26 to 50 employees.

The following conclusions were derived from the first research question:

- Organisations systematically monitor the use of financial resources for employee training but do not keep record of or evaluate such by area of training and work of the employees.

- The surveyed organisations measure the number of days of training per employee, whereby in the period 2003-2006 such number is constantly increasing, with certain areas recording a growth index of 1.8 (for 2009 it seems to be oversized, as it is expected to grow by over $200 \%$ compared to 2006 !).

- Organisations only exceptionally (only some of them) encourage, systematically establish, measure and reward the proposals for improvement (about half of the respondents not at all).

- In the periods under consideration, organisations used internal and external tools for quality development with an increasing frequency but failed to develop the indicators to evaluate the effects of such approaches in relation to the strategic goals of the public administration. 
Polonca Kovač, Barbara Leskovšek

Innovativeness as part of quality and excellence

development in the Slovenian public administration

- The more they take account of the changes in quality and excellence, the more evaluation schemes they actually use. However, they do not include the above approaches in their work or specific plans. The results are the same for internal and external approaches.

- The correlation between the (large) number of employees representing the critical mass and the use of the tools promoting continuous improvement and quality and innovativeness development is either weak or at least middle (according to the Pearson's correlation coefficient).

- As expected, in the periods considered organisations aimed at increasing the number of days for employee training in quality and excellence, human resources development and managerial skills improvement, and less in improving innovativeness. In addition, it was established that the organisations in public administration do not necessarily relate staff development to the development of quality and excellence, since the figures in training in human resources development and managerial skills improvement are significantly higher than - and thus non-related to - those in quality improvement.

- Organisations only keep financial data if the latter directly relate to the use of budgetary funds, i.e. by purpose rather than objective of use. Moreover, not even those with at least partially established system of improvement proposals gathering and evaluating assess net savings deriving from implemented improvement proposals.

- Although the organisations of the Slovenian administration - both individually and at the level of public administration as a whole - declaratively support the ideas and approaches of the new public management in the sense of assessing the results (management by objectives), the truth is that they only measure the inputs of, exclusively, financial resources.

The first research question was thus fully confirmed. Given the initially described restrictions and the limited degree of trust, we believe that the study question was posed absolutely correctly - with the additional statement that there is (yet) no systematic use of excellence and innovativeness development tools in the public administration. The organisations' awareness of the importance of the above approaches and the actual use thereof in the period considered and, in particular, in their plans demonstrates an evidently upward trend, although there is still a lack of empirical evaluations of the relevant effects. 
2. As far as the extent and results of the use of various excellence tools are concerned, a higher degree of innovativeness and better business results are demonstrated by the organisations that invest more in individual employees and in the organisation's development.

At the end of 2003-2006, the number of employees in quality management and business excellence rose on average by 9 and totalled 35.96; the same is expected for the period until 2009. Research and development employed 43.7 persons; their number increased on average by 24.8 in the period under consideration and shows a similar trend also for the period until 2009. Human resources development employed 14 persons - this number is expected to be at least preserved also in the following three-year period. Estimates for the above three areas show that financing is mainly allocated to employee training as a result to the increasingly prevailing trend among the employees - namely life-long learning - since both employers and employees are aware that in the present information society formally attained education soon becomes obsolete and it is necessary to continuously acquire new competences for a more efficient performance of work and higher level of competitiveness.

The frequency of introducing or using new tools and approaches per year was $15.71 \%$ in 2003, 20.71\% in 2006 and 28.57 in 2009. A slightly higher percentage was recorded also by the respondents whose replies related to threeyear periods: $9.29 \%$ in $2003,8.57 \%$ in 2006 and $4.29 \%$ in 2009 .

The respondents obviously prefer certain internal approaches over others, since in the periods concerned the same internal approaches obtained the same ranking, e.g. Quality Barometer and CAF self-assessment $1^{\text {st }}$ or $2^{\text {nd }}$ rank, comparisons with competitors or the best in the sector as part of the analysis for mainly strategic purposes (benchmarking) and introduction of process indicators regularly monitored by statistical tools $3^{\text {rd }}$ or $4^{\text {th }}$ rank, while the last two ranks $\left(15^{\text {th }}\right.$ and $\left.16^{\text {th }}\right)$ were occupied by 6 sigma and 20 keys systems. Such ranking reveals that organisations prefer internal approaches that are known to a broader circle of people, thus having better possibilities to compare the results with other similar organisations in the public sector in Slovenia and abroad. Moreover, in planning the future use of internal approaches to promoting innovativeness and quality they opt for tools which most of them already used in the previous period. 
Polonca Kovač, Barbara Leskovšek

Innovativeness as part of quality and excellence

development in the Slovenian public administration

The number of days of training per employee foreseen for 2009 is decreasing (down to 2.05 days), while the number of recorded proposals for improvement or innovations per employee is expected to grow (to 8.62 proposals); the same applies for the average share of implementation of the received proposals (47.53\%). In the period 2003-2006, all three variables increased: the number of training days per employee rose from 4.72 in 2003 to 7.9 in 2006, the number of recorded proposals from 3.34 in 2003 to 5.69 in 2006, and the average share of implementation of the received proposals from $27.59 \%$ in 2003 to $41.65 \%$ in 2006. Among the results obtained, only data on the expected number of days of training per employee in 2009 seems to stand out, which might be due to the introduction of e-government that initially required additional training in e-services for a large number of employees; once the system has come into operation, knowledge only needs upgrading and less training is necessary. Moreover, the said variable could also be under the effect of Slovenia's accession to the EU and the related need for training of competent employees which at the time considerably increased but has now taken the opposite direction.

The variables for which the Pearson's coefficient revealed correlation with the number of training days per year include: internal evaluation based on ISO 17025, ISO 17020 and similar, self-assessment according to the CAF excellence model, process indicators and regular monitoring of processes with statistical tools, and the use of the Quality Barometer. As regards 2009, it was noted that certain organisations strive to take advantage of the knowledge their employees obtain in training to enhance the use of the above internal approaches to promote continuous improvement and innovativeness and to improve quality and excellence, thus raising the quality of their services.

Organisations that in 2003 already had a plan for continuous improvement and innovativeness and greater quality and excellence recorded in the same year $43 \%$ of employees submitting 160 proposals in total; organisations without a plan recorded only $9 \%$ of employees presenting such proposals. In 2006, they recorded $43 \%$ of employees presenting 301 proposals and $16 \%$ employees presenting proposals, respectively. The share of the latter however increased by 7\% between 2003 and 2006. Organisations that in 2009 intend to introduce a plan for continuous improvement and innovativeness and greater quality and excellence are expected to record $49 \%$ of employees submitting 422 proposals in total, while the organisations without such intention for 2009 nevertheless expect to record $10 \%$ of employees presenting proposals. Quite 
obviously, the number of proposals anticipated by the organisations for 2009 increased in organisations which have or will produce a plan for continuous improvement and greater quality and excellence.

The correlation between the use of tools for continuous improvement and innovativeness of employees on one hand and the significance of procedures for recognising business quality by external (authorised) institutions on the other in 2006 is statistically characteristic of the Pearson correlation coefficient as $19.39 \%$ of coefficients proved correlation while $80.61 \%$ of coefficients did not. In 2009, statistically characteristic correlation was proven by $25.45 \%$ of coefficients among the pairs of variables.

In terms of individual groups, the highest shares of replies confirming the use of continuous improvement tools was recorded by administrative units, followed by municipalities (12.3\%), bodies affiliated to ministries, social work centres, ministries, institutes, and government services. The replies by public companies and the National Council were not positive.

Likewise, administrative units, followed by municipalities, institutes, social work centres and bodies affiliated with ministries, were the most likely to use specific approaches to assess continuous improvement. The replies by public companies, ministries, government services and the National Council were not positive.

In 2009 administrative units recorded a decrease in the elaboration of the above plans as only 31 organisations had such, compared to 35 in 2006 (equalling a drop from 81 to $72 \%$ of organisations within the group). Social work centres, municipalities, bodies affiliated with ministries and institutes are expected to increase the number of plans. No significant change compared to 2006 was recorded by public companies and government services.

It seems that the difference between administrative units and other segments of administration is decreasing or at least a decrease is planned, although it is a rather slow process that only points to the relevant trend; in absolute terms, administrative units are well ahead in the use of tools for continuous improvement, greater quality and excellence and innovativeness in all the years covered by the study.

The second research question as such can only be confirmed partially or it can only be concluded that the question can neither be proven nor overruled. This question is indeed harder to prove owing to the lack of uniform measurable and comparable indicators in the public administration as a whole, particularly those relating to the objectives of work. 
Polonca Kovač, Barbara Leskovšek

Innovativeness as part of quality and excellence

development in the Slovenian public administration

The fact is that if the volume of input (human resources, finance, training) in quality, excellence and innovativeness is increasing, organisations are indeed aware of the significance of these areas and change their rather uncontrolled approach for a more systematic one.

The following conclusions can be drawn:

- Organisations distinguish between human resources development on one side and business excellence development and innovativeness on the other, and do not correlate them. The number of employees in human resources development is significantly higher than of those engaged in quality management and research and development; the latter two however show an upward trend while the first shows a slightly downward trend.

- The growth of inputs should lead to higher number of submitted and implemented proposals for improvement as a basic indicator of innovativeness of individuals and the organisation as a whole. Such correlation is partially seen only between 2003 and 2006 although it is only a middle correlation, not even stated for 2009.

- Planning as a systematic approach is fruitful since organisations with elaborated continuous improvement plans obviously record a larger number of improvement proposals.

- The growth of inputs (human resources, finance, training) in quality, excellence and innovativeness leads to increasingly frequent or wider in terms of volume (number of approaches) - use of tools in general, mainly internal and external evaluation procedures, taking into account both the comparison between 2003 and 2006 and the plans for 2009 when the most frequently used tools should be used regularly once a year.

- Attention is drawn also to the unequal rate of use of the tools in various parts of public administration, e.g. social work centres do not use them, supposedly due to insufficient involvement of the line ministry.

None of the above assumptions may be proven because either the organisations do not keep record of such data or there is actually no correlation, not even between the number of training days and the volume of submitted proposals for improvement. A more frequent use of the tools was recorded, yet not for all the three elements of the study (partly for tools in general and 
internal approaches, but not at all for external procedures) and differently in different periods of time.

The largest share of positive replies about the use of tools for continuous improvement in individual groups compared to the overall statistical sample goes to administrative units $(50.8 \%)$, followed by municipalities $(12.3 \%)$, bodies affiliated with ministries $(10.8 \%)$ and social work centres $(9.2 \%)$, ministries $(6.2 \%)$, institutes $(6.2 \%)$ and government services $(4.6 \%)$. The same applies to measuring continuous improvement. Administrative units also recorded the largest share of positive replies about plans promoting continuous improvement in the period 2003-2006. Such share was 58.8\% in 2003 and $60.3 \%$ in 2006, while projections for 2009 indicate that it will account for $49.2 \%$ of the public administration as a whole.

\section{Financial inputs by the organisations and their impact on results}

The 140 organisations surveyed together employ 17,122 persons; 53 organisations have less than 25 employees, 42 have 26-50 employees, and 44 have more than 50 employees. The size of the organisation has no effect on the frequency of use of the tools for continuous improvement and for raising innovativeness among the employees. The statistical correlation based on the Pearson's correlation coefficient is observed only in organisations with 26-50 employees that use the ISO system and the CAF model, both in terms of internal and external evaluation and follow-up. Organisations with less than 25 employees are the most reluctant to use improvement tools that contribute to quality and excellence as well as innovativeness. In 2003, organisations on average recorded the lowest number of employees in quality management and business excellence; here, also the arithmetic mean based on the total number of employees is the lowest and amounts to 0.50 . The lowest estimated values relating to the number of employees in 2003 were indicated in research and development and in 2006 in quality management and business excellence. The highest numbers of employees in 2009 are expected on average in research and development.

As a general rule, surveys were answered on behalf of the organisation by the heads of such organisations (30\%), followed by the "person performing 
Polonca Kovač, Barbara Leskovšek

Innovativeness as part of quality and excellence

development in the Slovenian public administration

other tasks « (23.6\%) and heads of internal organisational units (19.3\%), which indirectly shows who in the hierarchy of an organisation is in charge of the development of quality, excellence and innovativeness. It was established that compared with the findings for the private sector (Kovač, 1999), various analyses of the use of the EFOM model in Slovenia and abroad indicate (Kovač, 2007a) that such person is much too seldom - only in one third of the cases the top manager of the organisation. If this is an issue that falls within the domain of hierarchical levels below the head of the organisation, it acquires an operational (rather than strategic) and thus understated connotation, which as a consequence reduces the potential effects of the use of TOM tools.

In 2003, organisations on average allocated the least financial resources to promoting continuous improvement and staff innovativeness as demonstrated by the lowest value of the arithmetic mean (approx. EUR 2500), but are expected to increase such figures in 2006 and 2009 to 3900 or, according to the plan, EUR 4400 respectively. Most financing is intended for staff training, with extremely high arithmetic means for all three years under consideration - over EUR 21,000 in 2003, almost EUR 28,000 in 2006, and almost EUR 36,000 planned for 2009.

On average, organisations estimate that in the future (in 2009) most financing will be allocated to research and development given that it records the highest arithmetic mean - almost EUR 40,000 although slightly above EUR 35,700 in 2006 and only EUR 19,000 in 2003. The standard deviation from the values of the arithmetic means indicates that the estimated financial resources in EUR on average differed from the arithmetic mean by various amounts that varied considerably from one group of replies to the other. The most outstanding are the values of the standard deviation of replies in research and development. This points to an uneven use and planned distribution of financial resources by individual organisations.

In 2009, organisations plan to reduce the number of trainings per employee by $2 \%$ on average compared to 2006 , namely in quality and excellence development, human resources development, and improvement of managerial skills, and increase training related to improving innovativeness by $4 \%$. The lowest average number of days of training per employee was recorded in 2003, namely in quality and business excellence improvement with arithmetic mean values of 27.6 days compared to 41.7 days in 2006 and the planned 47.5 days in 2009. 
Polonca Kovač, Barbara Leskovšek

Innovativeness as part of quality and excellence development in the Slovenian public administration

\section{Continuous improvement, innovativeness, and greater quality and excellence - findings}

In public administration, the respondents mainly use customer satisfaction surveys, Quality Barometer, the ISO system and CAF model, as well as other tools, but are unfamiliar with others, as expected (e.g. 20 keys, 6 sigma etc., and in particular the tools and procedures characteristic for small and mediumsized enterprises).

Figure 2: Use of continuous improvement tools by organisation (based on 140 replies), in \%

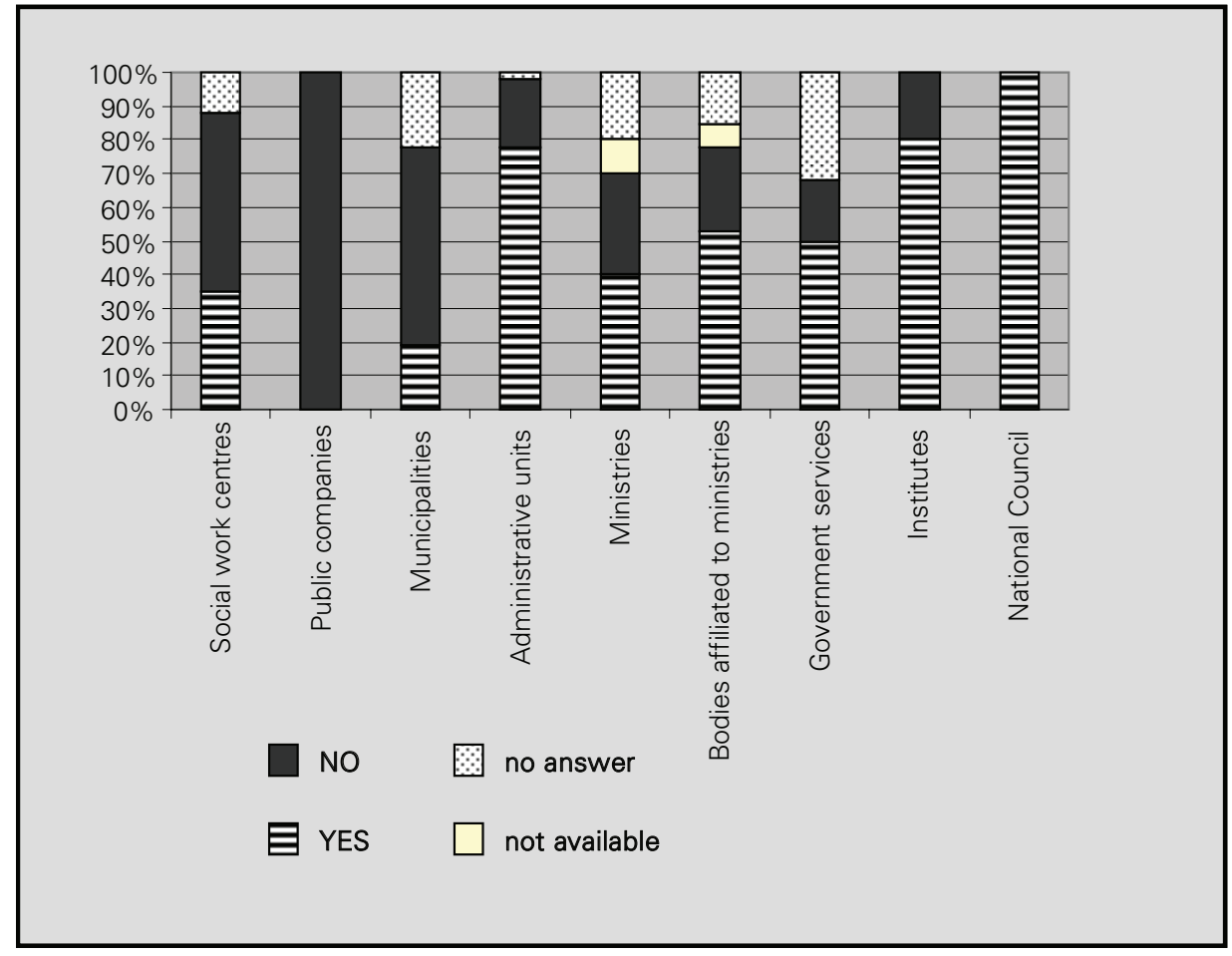

In $20 \%$ of the cases the organisations replied that they assessed the number and value of proposals for continuous improvement and innovativeness, while in $66.43 \%$ of the cases these data were neither kept nor assessed. In 2003-2006, the number of recorded proposals increased from $3 \%$ to $6 \%$ (the average increase planned was $8,6 \%$ ), similarly to the number of proposals 
Polonca Kovač, Barbara Leskovšek

Innovativeness as part of quality and excellence

development in the Slovenian public administration

by employees which rose from $4 \%$ (2003) to almost $6 \%$ of employees (2006), with a plan of nearly $13 \%$ proposers among all employees of the organisation.

The average reward received by employees for a submitted and implemented improvement proposal increased from EUR 100 in 2003 to over EUR 200 in 2006. Organisations recorded the smallest share of implementation of proposals for continuous improvement and innovations in 2003 when the arithmetic mean was the lowest $(27.6 \%)$, but in the years to come the percentage of implementation is (planned) to increase (to 42 or $48 \%$, respectively). The organisations record the least of the data that could serve as basis to assess the average net savings as a result of the proposals $(17-22 \%$ of all replies received). Significant saving is expected no sooner than 2009 where the arithmetic mean is the highest (EUR 3200 compared to around EUR 860 in 2003 and 1760 in 2006), but it is not clear how such plans and expectations are justified.

Among all the participants, the question whether the organisation used tools for continuous improvement and innovativeness received $47 \%$ of positive replies, $39 \%$ of organisations do not make use of such tools, $13 \%$ did not reply, and two organisations (1\%) did not record such data.

According to the classification of replies by the frequency of use of internal approaches, organisations do not use or are even unfamiliar with internal approaches for continuous improvement. In terms of their size, internal approaches are not used in general by $48 \%$ of organisations with less than 50 employees and by $24 \%$ of those with more than 50 employees. Internal approaches most widely and regularly used in public administration include selfassessment according to CAF model, internal assessment according to ISO 9001:2000, benchmarking and Quality Barometer. Occasionally, but very rarely, organisations resort to gathering and rewarding useful proposals and improvements, present their own quality and good practice system at conferences and conventions, etc. In 2009, the frequency of use of certain internal approaches, particularly the CAF model and the gathering of useful proposals and improvements, is expected to increase. In 2006, organisations most often used self-assessment according to CAF, process indicators, Quality Barometer, and the system of gathering and rewarding proposals and improvements. Over $60 \%$ of organisations did not know or use one of the most common approaches, i.e. internal assessment according to ISO 9001:2000; the latter was used by only 28 organisations. This will probably change in 2009 as the share 
of organisations familiar with and using the above approach is expected to grow.

We also examined the use of external procedures. Here, the 2006 average values range between a minimum of 0.27 (importance of successful cooperation in quality projects supported by the Small Business Promotion Centre or the Public Agency for Entrepreneurship and Foreign Investments - small organisations) and a maximum of 1.83 (importance of the certified system of business quality management ISO 9001:2000). The maximum estimated value for 2009 is 2.64 for importance of assessment according to the CAF model by external evaluators or participation in the pilot project of external assessment according to the same model. Organisations highlight the importance of the CAF model also for external - and not only internal - evaluation. Moreover, the hitherto trend (observed in 2003 and particularly in 2006) regarding participation in the Ministry of Public Administration's public tender on good practices, in Business Excellence Award projects and in competitions for quality awards, and certified quality management system ISO 9001:2000 is expected to continue. In such context, organisations distinguish between business quality awards by individual external institutions and attach particular importance to those fitted to public administration, while they do not know others or even reject them.

$24 \%$ of participating organisations had a plan for continuous improvement in $2003,42 \%$ had such in 2006 , and $45 \%$ are expected to elaborate a plan in 2009.

\section{Final conclusions}

If quality or excellence development is assessed by the use of tools, internal and external evaluations, systematic encouragement of proposals for improvement and planning, all in the context of increased inputs in human resources management and development - particularly training - and finance, there is no doubt that (1) there is statistically typical increase in the use of such tools which, however, (2) is not systematic neither at the level of most individual organisations nor in the public administration as a whole (they are mainly used only in administrative units). The recommendation for the competent authorities is to reconsider the objectives of public administration and adopt 
Polonca Kovač, Barbara Leskovšek

Innovativeness as part of quality and excellence

development in the Slovenian public administration

and implement a plan of activities to improve the use of the approaches studied. This also derives from Slovenia's Development Strategy relating to the period 2006-2013 (prepared in 2003-2004 and approved in 2005).

Undoubtedly, an upward trend regarding the use of such tools is observed both in individual organisations and units and in the public administration as a whole. The trend is mainly progressive, meaning that the difference between 2009 and 2006 is greater than between 2006 and 2003, although the plans for 2009 should be regarded with some reserve given the lack of support with guaranteed resources. Investment into resources is, on one hand, a factor of development and a consequence thereof on the other, and the spiral of organisations involved in continuous improvement procedures is infinite. Attention needs to be drawn to the fact that it would be wise to examine the actual impacts of increasing inputs and of the use of quality and excellence tools on the implementation of the objectives of public administration. In terms of methodology, such approach is certainly very good practice to be applied in as many projects as possible related to a wider social context.

Last but not least, the purpose of the project was to enable and provide an opportunity to as many organisations in the Slovenian public administration (and private companies) as possible to compare with and learn from other similar or different public administration organisations (Kovač et al., 2007) and introduce good practices in all types of organisations of public administration and - on a longer run - in the entire public sector. The originality of good practice derives mainly from the correlation of various systems within state administration and from cooperation with the users in the private sector ${ }^{\boldsymbol{9}}$. The findings of this study will be very useful for both the employees in public administration and - in particular - to decision-makers at the State level when developing public policies on the functioning of public administration taking into account the changed role of the State both in adopting strategic decisions and preparing the relevant documents as well as in their implementation.

The organisations of the Slovenian administration - both individually and at the level of public administration as a whole - only declaratively support the ideas and approaches of the new public management in the sense of assessing the results; the truth is that they assess (only) the inputs of financial resources. Evidently, the frequency of use is increasing over time (2003-2009), but empirical evaluations of the effects of such use are still lacking. There is an uneven rate of use of the tools in individual parts of public administration,

9 Smodiš, 2005, p. 599. 


\section{Polonca Kovač, Barbara Leskovšek \\ Innovativeness as part of quality and excellence development in the Slovenian public administration}

mostly in administrative units. According to the results of the study, quality and excellence development in the Slovenian public administration is - despite the remarkable results of individual organisations - still at an initial stage. Therefore, the main task for the competent authorities is to pursue further activities only after prior target-oriented analyses of public policies and redefinition of strategic goals of development of the State and its administration.

Polonca Kovač completed her PhD studies at the Faculty of Law of Ljubljana in November 2005 with a thesis on public authority in the Republic of Slovenia. Since 2001 she has been employed full-time at the Faculty of Administration where she is lecturer at several first- and second-level courses, also collaborating with the Faculty of Social Work, Faculty of Criminal Justice and Security, Faculty of Economics, and Faculty of Social Sciences. Since the late 1990s, she has been giving seminars and workshops and presenting and publishing papers at national and international conferences. In 2007 she was appointed Assistant Professor for public administration. She has been an evaluator since 2002 and acted as arbitrator in the procedure regarding the Slovenian Business Excellence Award between 2004 and 2008; she now holds a second term of office for the period 2009-2012. She is also evaluator in quality assessment procedures for higher education programmes and institutes. Since 2008 she has been member of the Senate of the Faculty of Administration. She is member of the Government Strategic Council for the public sector. In December 2008 she was appointed member of the Council of Officials and has been chairing this body since last July.

Barbara Leskovšek is a specialist in public administration completing a postgraduate master's course in administration at the Faculty of Administration. She concluded hitherto studies as the graduate of the year. She graduated in comparative analysis of eportals in Slovenia and abroad and specialised in comparative analysis of European framework programmes. She presented her findings at several national conferences. She has been employed at the Faculty of Administration since February 2004 as autonomous specialised staff member for science and research. In such context, she has been actively involved in the preparation of numerous national and European projects and has been member of organisational boards for several international conferences and conventions (NISPAcee, EGPA, SSPA). 


\section{Polonca Kovač, Barbara Leskovšek Innovativeness as part of quality and excellence development in the Slovenian public administration}

\section{Bibliography and sources}

\section{Bibliography}

- Ambrožič, M. (2005). Anketna metoda. V: šauperl, A. (ur.). Raziskovalne metode v bibliotekarstvu, informacijski znanosti in bibliotekarstvu. Ljubljana: Faculty of Arts of the University of Ljubljana. Department of Library and Information Science and Book Studies. Available at: Informacijski portal za promocijo znanosti, http://www.znanstveniki.si/ (5. 2 2008).

- Dolinšek, S. et al. (2006). Management kakovosti. Lecture notes. Portorož, Faculty of Management.

- Kovač, P. (1999). Možnosti in ovire pri prenosu podjetniških konceptov dela iz zasebnega v javni sektor. Kranj: Organizacija, year 32, No. 4, 198-204.

- Kovač, P. (2003). Skupni ocenjevalni okvir žCAF' kot most do globalizacije v javnih upravah Evropske unije. V: Brezovšek, M., Haček, M. (ur.). Globalizacija in državna uprava. 1. izd. Ljubljana: Faculty of Social Sciences, 151-164.

- Kovač, P. (2004): Organizacijska kultura na podlagi evropskega modela odličnosti v javnem sektorju - CAF. Ljubljana: HRM, year 2, No. 3, 42-45.

- Kovač, P., \& Kern Pipan, K. (2005). Evropski model odličnosti EFQM kot optimalno orodje razvoja odlične slovenske javne uprave = European model of excellence EFOM as a tool the development of excellence Slovene public administration. Ljubljana: Javna uprava, year 41, No. 4, 723-742.

- Kovač, P. (2006): Pravni in sociološki vidiki javnih pooblastil, Ljubljana: Faculty of Administration.

- Kovač, P. (ur.), Tomaževič, N. (ur.), Drnovšek, D., Kern - Pipan, K., Krajnik, P., Preskar, J. \& Rman, M. (2007). Razvoj in vzpostavitev sistema ocenjevanja odličnosti v javni upravi (SOOJU). Final project report. Ljubljana: Faculty of Administration.

- Kovač, P. (2007a). Razvoj kakovosti in odličnosti v javnem sektorju po evropskih modelih EFOM in CAF. V: Reforme $v$ negospodarstvu : 23 to 24 March 2006, Bled. Ljubljana: Management Agency, 59-64.

- Loeffler, E. (2006). Evropska spoznanja - inovacije v kakovosti javnega sektorja. Proceedings of the conference Dobre prakse. Ljubljana: Ministry of Public Administration, 23-33.

- Marolt, J. \& Gomišček, B. (2005). Management kakovosti. Kranj: Moderna organizacija.

- Nemec, T. (2003). Kakovost v upravi - kako in s čim, http://upravneenote.gov.si/fileadmin/pageuploads/ueljutomer/jpg/Kakovost/Prispevki/Kakovost_v_upravi.pdf (8. 1. 2008). 
- Savič, N., Kern Pipan, K. \& Gunčar, U. (2007). Poslovati odlično z uporabo Modela odličnosti EFQM. Ljubljana: Public Agency of the Republic of Slovenia for Entrepreneurship and Foreign Investments.

- Šmidovnik, J. (1985). Teoretične osnove upravljanja. Ljubljana: College of Administration.

- $\quad$ Toš, N. \& Hafner - Fink, M. (1998). Metode družboslovnega raziskovanja. Ljubljana: Faculty of Social Sciences of the University of Ljubljana.

- Virant, G. (2007). O inovativnosti v javni upravi. Ljubljana: Javna uprava, year 43, No. 1, p. 255-266.

- Žargi, D. (ur.), et al. (2007). Kakovost: inovativnost in odgovornost. Proceedings of the $16^{\text {th }}$ annual conference. Ljubljana: Slovenian Quality Association.

\section{Sources}

- CAF 2006 Brochure. Retrieved 29. 7. 2007, from CAF: http://www.eipa.eu/files/File/CAF/Brochure2006/English_2006.pdf.

- CAF Regional Bench Learning Project. Retrieved 30. 6. 2007, from CAF: http://www.4qconference.org/liitetiedostot/caf_presentations/CAF2.2_Kallinger.pdf.

- CAF works - better service for the citizens by using CAF (2006). Retrieved 14. 5. 2007, from CAF: http://www.eipa.eu/files/repository/product/CAFworks_EN.pdf.

- Ministry of Public Administration. Retrieved 15. 7. 2008, from Ministrstvo za javno upravo: http:www.mju.gov.si.

- Ministry of Public Administration. Skupni ocenjevalni okvir. CAF. Retrieved 25. 4. 2007, from Ministrstvo za javno upravo:

http://www.mju.gov.si/si/delovna_podrocja/kakovost_v_javni_upravi/skupni_ocenjevalni_ okvir_caf, 25. 04. 2007.

- Common Assessment Framework for organisations in the public sector/model CAF 2006 (2007). Retrieved 15. 7. 2008, from Ministrstvo za javno upravo:

http://www.mju.gov.si/fileadmin/mju.gov.si/pageuploads/mju_dokumenti/pdf/CAF_2006_ _SLO_.pdf.

- Government Office for Legislation. Register of Regulations of the Republic of Slovenia. Retrieved 16. 8. 2007, from Služba Vlade RS za zakonodajo: http://zakonodaja.gov.si

- Institute of Macroeconomic Analyses and Development. Slovenia's Development Strategy . Retrieved 25. 4. 2007, from Urad Republike Slovenije za makroekonomske analize in razvoj:

http://www.slovenijajutri.gov.si/fileadmin/urednik/dokumenti/strategija_razvoja_slovenije. pdf. 
Polonca Kovač, Barbara Leskovšek Innovativeness as part of quality and excellence development in the Slovenian public administration

- Metrology Institute of the Republic of Slovenia. Slovenian Business Excellence Award. Retrieved 16. 8. 2007, from Urad RS za meroslovje:

http://www.mirs.si/delovna_podrocja/prspo/

- Decree on Administrative Operations. Official Gazette of the Republic of Slovenia No. 20/05, 106/05, 30/06, 86/06, 32/07, 63/07. Retrieved 7. 8. 2007,

http://www.eipa.eu/CAF/CAF_2006/Brochures/Slovania_2006.pdf.

- Access to Public Information Act. Official Gazette of the Republic of Slovenia No. 24/03, 61/05, 109/05-ZDavP-1B, 113/05-ZInfP, 28/06, 117/06-ZDavP-2, 51/06-UPB2.

- The Republic of Slovenia Business Excellence Award Act. Ur. I. RS, št. 22/98, 55/03, 92/07. 